\title{
Jopi Nyman. Displacement, Memory, and Travel in Contemporary Migrant Writing
}

Textet: Studies in Comparative Literature 83. Leiden: Brill, 2017. 260 p. ISBN 978900434 2064. €90

\section{Helga Ramsey-Kurz}

\section{OpenEdition}

\section{Journals}

Electronic version

URL: https://journals.openedition.org/ces/406

DOI: $10.4000 /$ ces. 406

ISSN: 2534-6695

\section{Publisher}

SEPC (Société d'études des pays du Commonwealth)

\section{Printed version}

Date of publication: 30 November 2018

Number of pages: 149-150

ISSN: 2270-0633

\section{Electronic reference}

Helga Ramsey-Kurz, "Jopi Nyman. Displacement, Memory, and Travel in Contemporary Migrant Writing", Commonwealth Essays and Studies [Online], 41.1 | 2018, Online since 05 November 2019, connection on 23 August 2021. URL: http://journals.openedition.org/ces/406 ; DOI: https://doi.org/10.4000/ces. 406

\section{(C) $\Theta \Theta \Theta$}

Commonwealth Essays and Studies is licensed under a Licence Creative Commons Attribution - Pas d'Utilisation Commerciale - Pas de Modification 4.0 International. 
Displacement, Memory, and Travel in Contemporary Migrant Writing. Textet: Studies in Comparative Literature 83. By Jopi Nyman. Leiden: Brill, 2017. 260 p. ISBN: 978-9004-34206-4. €90.

Reviewed by Helga RamsEY-Kurz

There has been a growing need in migrant studies in recent years for new approaches to the plight of forcibly displaced persons. Typically concerned with human mobility, postcolonial critique has helped meet this need through such formidable studies as Postcolonial Asylum (2011) by David Farrier, Contemporary Asylum Narratives (2014) by Agnes Woolley, or Performing Noncitizenship (2015) by Emma Cox. All three advance powerful critiques of the nation state which, despite repeated assertions of its obsolescence in the age of globalisation (e.g. in the Guardian article "The Demise of the Nation State" by novelist Rana Dasgupta [April 2018]), is thriving in the wake of current mass migrations and the new nationalisms to which they have given rise.

Displacement, Memory, and Travel in Contemporary Migrant Writing by Jopi Nyman also takes on the nation state, albeit only as effectively as can be expected of a collection of essays that reworks publications predating the 2015 refugee crisis by up to six years. Grouped in three parts titled "Refugees and Displaced Migrants," "Memories and Migration," and "Migration, Travel, and Postcolonial Europe," these essays are meant to contest "such forms of postcolonial discourse that celebrate [migration and hybridity] as unproblematic ways of countering hierarchies and hegemonies" (1). For Nyman, reproblematising migration in the face of routine claims of its universality seems to mean comprehending displaced subjects as persons struggling to "(re)construct" (4), "shape" (94), "fix" and "pin down" (166) their broken or lost identities in what he calls "transnational spaces" (n.p.). Accordingly, he begins his book with a discussion of poems and short stories that emerged from a writing project with refugees in Wales. The texts combine recollections of famine, censorship, human rights violations and rebel wars in Africa with experiences of racist aggression in Europe, and, as Nyman shows, systematically eclipse Britain as a new homeland or overwrite it with celebrations of sites of joint literary production. At such sites, Nyman explains, quoting Marc Augé (Non-Places, 1995), "the nonplace becomes a place, 'relational, historical and concerned with identity" (29). Drawing on Upstone's concept of post-space (Spatial Politics in the Postcolonial Novel, 2009), Nyman proceeds to elaborate on narration as "an alternative kind of journeying" unrestrained by "the nation-state and its practices of exclusion" (41), doing so in three essays on Going Home (2005) by Simão Kikamba, A Long Way Gone: Memoirs of a Boy Soldier (2007) by Ishmael Beah, and the short story "Last Thoughts on the Medusa" (2008) by Jamal Mahjoub.

Remembrance provides a thematic link between the essays in Part 2, which begins with a chapter on the cultural significance of food and its representation in culinary memoirs Climbing the Mango Trees (2005) by Madhur Jaffrey and The Language of Baklava (2005) by Diana Abu-Jaber. The transition to Adulrazak Gurnah's Pilgrims Way (1988) and Caryl Phillips' Dancing in the Dark (2005) appears abrupt and insufficiently accounted for by "the affective register" (92) of which, Nyman claims, all four writers make comparable use. Reading Pilgrims Way against Freudian and post-Freudian theories of mourning and melancholia, Nyman suggests comprehending the racist violence 
Gurnah's protagonist faces in contemporary Britain as a prolongation of the trauma he suffered in Zanzibar and which is eventually transformed, through the act of narration, into collective experience. By stark contrast, Nyman interprets Dancing in the Dark (2005) as an unconditionally pessimistic appraisal of the vaudeville artist Bert Williams' professional entrapment in the tradition of blackface. For Nyman, Williams performs a self-betrayal so complete that "it can only lead to despair and loneliness" (151). Unlike any of the other texts discussed, Nyman further argues, Phillips' novel grants no transnational space where the artist's self-debasement can be undone. This is in somewhat puzzling contradiction to Nyman's assertion, earlier in his book, that narration itself ought to be seen as constituting just such a space. One should think that, by inference, Phillips' reconstruction of Williams' life ought to be comprehended as a particularly powerful claim to a space beyond national fantasies of belonging. Yet Nyman's collection is not designed to develop the ideas formulated in its individual chapters into a cohesive theoretical framework. The elaboration of his notion of transnational space remains a desideratum, leaving unexplained how it compares to Bhabha's Third Space - a "site of the formation of hybrid identity, "where it is possible to feel the estranging sense of the relocation of the home and the world - the unhomeliness - that is the condition of extra-territorial and cross-cultural initiations" (The Location of Culture, 1994, 9). Is "extra-territorial and cross-cultural initiation" not precisely what Nyman claims that transnational spaces afford? Do the transnational spaces he posits not bring forth exactly the same "sense of relocation of the home" Bhabha writes about? Is it not in such relocations that Nyman too envisages the (trans)formation of migrant identities into hybrid forms?

Such questions remain unanswered also in the final part of Nyman's book, which examines Europe as a space of transnational encounters in The Drift Latitudes (2006) and Travelling with Djinns (2003) by Jamal Mahjoub, and Alentejo Blue (2006) and In the Kitchen (2009) by Monica Ali. Nyman recalls Sandra Ponzanesi and Daniela Merolla suggesting, back in 2005, that "the European borderline is now being redefined by voices which once were excluded or marginalized from its main body," thereby reinforcing his own claim that the border "does not only separate but also brings together various actors, and creates new modes and spaces of interaction, new borderscapes where identities, belonging, and citizenship are negotiated and reconstructed" (6). Reading this in 2018, one cannot help thinking of the Mediterranean, Europe's most deadly border, and wondering how Nyman could have overlooked the chilling datedness of his optimism and made no attempt to curb it. Without such correction, his collection conveys the rather unfortunate impression that it seeks to capitalize on the sad topicality of the theme of migration without confronting it. 